This is a self-archived version of an original article. This version may differ from the original in pagination and typographic details.

Author(s): Ala-Vähälä, Timo

Title: Reception of the quality assurance commitments of the Bologna process in Finnish higher education institutions

Year: 2016

Version: Accepted version (Final draft)

Copyright: (c) 2016 Taylor \& Francis

Rights: In Copyright

Rights url: http://rightsstatements.org/page/InC/1.0/?language=en

Please cite the original version:

Ala-Vähälä, T. (2016). Reception of the quality assurance commitments of the Bologna process in Finnish higher education institutions. Quality in Higher Education, 22(2), 103-116.

https://doi.org/10.1080/13538322.2016.1195966 
TIMO ALA-VÄHÄLÄ

University of Jyväskylä, Department of Social and Public Policy, PO Box 35, 40014, Finland. timo.ala-vahala@jyu.fi

\title{
Reception of the quality assurance commitments of the Bologna process in Finnish higher education institutions
}

\begin{abstract}
This article analyses Finnish higher education institutions' reception of the implementation of the new quality assurance systems that governments participating in the Bologna Process have committed to establishing in the Berlin Communique (2003). The data was collected using a websurvey, and the respondents were classified with a cluster analysis.

The reception was more positive in the polytechnics than in the research universities, and women were more positive than men. People working in managerial positions were most positive about, and committed to, quality assurance. Most critical were young researchers in research universities working in temporary jobs. Some opinions were so strongly shared that respondents with short work experience expressed their opinions, even though they could not have personal experience of the topic in question. In some topics, respondents without personal experience, but having a critical attitude tended to give their opinion, whereas those with neutral attitude rather abstained from commenting.
\end{abstract}

Keywords: Bologna Process; Berlin Communiqué; quality assurance; implementation; university personnel.

\section{Introduction}

This article analyses the reception of the new quality assurance structures that governments participating in the Bologna Process have committed to establishing. In this context, reception pertains to the following three topics: first, the respondents' assessments of the main motivations for building the quality assurance systems; second, the respondents' general attitudes toward quality assurance; third, the respondents' commitment to, and expertise in, quality work.

Alongside the quality assurance systems and their audits, carried out by the Finnish Higher Education Evaluation Council (FINHEEC), was the Finnish response to the aim of implementing the 'accreditation or similar procedure' of external quality assurance in member countries, as stated in the Berlin Communiqué of 2003. Due to the fact that systems of quality assurance were either rudimentary or completely non-existent in Finnish research universities, setting up audits of the universities' quality assurance systems first necessitated their creation. Polytechnics already had a tradition of quality work and various kinds of audits but developing the system of quality assurance was also a challenge for them (Ala-Vähälä, 2011).

Since the early 1990s, the Finnish system of higher education has been a dual system consisting of research universities and polytechnics. Polytechnics were founded by merging vocational postsecondary education units. They had been owned by municipalities, foundations and other societies but their main funding has come from the government, which also grants their licences to provide 
education. From the 1970s to 2009, all research universities were public institutions. In 2009, the new Universities Law (558/2009) made Finnish universities either independent corporations under public law or foundations under private law. Before 2016, Finnish higher education institutions did not have the right to demand tuition fees but from 2016 they can require fees be paid by students coming from outside the EU and the European Economic Area (Laki yliopistolain muuttamisesta, 1600/2015. Laki ammattikorkeakoululain muuttamisesta, 1601/2015).

According to Talvinen (2012), the new quality assurance systems in Finland consist of descriptions of procedure in quality manuals, systems for gathering information (data, feedback), and systems for improvement-oriented planning, which is usually a version of the Deming Cycle of Total Quality Management that includes the following steps: Plan, Do, Check, Act (PDCA). Talvinen (2012) also stressed the close connection between quality work and management in an ideal system of quality assurance.

The implementation of the Finnish system of audits has been discussed in Eklund (2013) and Haapakorpi (2011). These studies analyse the political context of audits; especially Eklund's study and, in the case of Haapakorpi's study, the impacts of audits in different disciplinary contexts are considered. Several studies mention academic personnel's experience of increased workload and the frustrating amount of work that is required in comparison to the perceived benefits of quality assurance and they also highlight the demoralising effects of implementing such a new system (Haapakorpi, 2011; Hoecht, 2006; Anderson, 2006; Newton, 2002). Rinne et al. reported on increased workloads, the incompatibility of the concept of quality assurance and academic work, and the experience of polishing a university's image rather than improving the quality of its education (Rinne et al., 2012).

Ala-Vähälä (2011) and Ala-Vähälä and Saarinen (2013) stated that the people working in polytechnics have more positive attitudes towards quality assurance than those working in research universities. In general, people in managerial positions, especially in top management, are the most receptive of this type of quality assurance, while researchers working in research universities are the most critical.

Cardoso et al. (2012) mentioned that academics tend to support quality assessment mechanisms aiming at improvement rather than control. This support is slightly higher among female academics and among academics from public polytechnic institutions, from medical and health sciences, and among people with previous experience in quality assurance activities. Rosa et al. (2012) stressed that academic personnel may accept improvement-oriented quality work but are critical of demands for external control or accountability, especially demands for meeting standards that are defined by those outside the academic community. They may also believe that external quality assurance does not fully grasp the nature of academic work.

According to Newton $(2000 ; 2002)$, academics who participate in the implementation of the quality initiatives insert their own interpretations of the quality system when they are able to contribute. In that sense, they are not passive recipients of management objectives; instead, they shape the quality policy as they participate in its implementation. Newton also mentions a 'gap' between academic managers and other academics, with the former having more positive attitudes towards quality assurance than the latter. On the other hand, Brunetto and Farr-Wharton (2005) suggested that if the financial support provided for the implementation of the new quality system is lacking, academics in managerial positions do not implement the system at the operational level, even though they may make formal policy statements in support of the quality initiatives.

In sum, previous research has covered topics related to the modes of implementing new structures of quality assurance and various types of critical attitudes towards new systems of quality assurance. However, a systematic analysis of how university personnel have accepted or rejected the new forms of quality assurance has yet to be undertaken. Ala-Vähälä (2011) and Cardoso et al. 
(2012) have discussed the differences between various personnel groups but these results require further analysis because they do not reveal what specific kinds of personnel are under discussion. Although numerous studies have addressed the recent changes in the structure of academic professions (Nyhagen, Mathisen, \& Baschung, 2013; Hakala, 2008; Akskling, 2001; De Veert, 2001; Shattock, 2001), the problem of classifying university personnel has not been discussed in this context.

\section{Target groups, collection of the data, response rate}

This study is based on data collected in 2009 from four Finnish multidisciplinary research universities and four polytechnics. At that time, all the higher education institutions surveyed had built their quality assurance systems and gone through the audit process.

The data was collected using a web-based survey. To recruit participants from research universities, the invitation to take part in the survey was sent to administration and support services personnel and to the personnel in faculties of social sciences at all the universities, personnel from educational sciences at all the universities, and personnel from the natural sciences at three universities, and faculties of law in two universities. To recruit participants from the polytechnics, the invitation was sent to administration and support services personnel and to personnel in four fields of study: social services, health, and sport; technology, communication, and sport; social sciences, business and administration; and culture (in three polytechnics). These fields of study were selected because they offered a broad range of courses and were provided in the majority of the higher education institutions that were willing to participate in this study.

From the research universities, the survey received 511 responses, which was quite low at $8.9 \%$ of the total amount of the personnel. From the polytechnics, the response rate was a bit higher, at $21.3 \%$ with 390 responses (Tables 1 and 2). Lecturers were overrepresented in both groups and non-academic personnel were underrepresented in research universities. Although the response rate was relatively low, the total number of respondents was quite large, which makes it possible to explore their various attitudes connected to quality assurance.

Table 1. here

Table 2. here

\section{Classification of the respondents}

Due to their different historical roots, job titles and working contexts differ between polytechnics and research universities. Therefore, it is reasonable to expect that the personnel groups are not homogenous and that their tasks and professional roles may overlap. In order to resolve these incompatibilities, the respondents were classified using cluster analysis.

The cluster analysis was carried out using a hierarchical cluster analysis (Ward's method). The criteria were measured using squared Euclidean distances and values standardised to z-scores, and this was based on the responses to the following statements or questions:

1. Research activities: 'I carry out research full-time or part-time along with other activities'.

2. Research and development (R\&D) activities in co-operation with companies: 'I participate regularly in the research or development work that is undertaken together with private business or public administration'.

3. Commitment to own institution: 'I participate actively in various working groups, teams, networks or decision forums that have an impact in the activities of my university or polytechnic'. 
4. Networking and contacts with colleagues: 'I meet regularly people with same expertise in national or international forums'.

5. Networking and contacts with companies, business organisations, and public sector representatives: 'I keep regular contact with private companies, public sector units or representatives of business federations'.

6. Age.

7. Level of education: doctoral degree $(1=$ yes, $0=$ no $)$.

8. Managerial or expert position $(1=$ yes, $0=$ no $)$.

9. Teaches $(1=$ yes, $0=$ no $)$.

10. Permanent full-time job $=1$; other types of jobs (temporary jobs, part-time jobs etc.) $=0$.

The variables were selected so that the analysis would make it possible to classify the personnel according to their various commitments, academic or administrative careers, level of education, and networking activity with various stakeholder groups. The analysis yielded eight clusters, as follows:

1. Research-oriented academics: mainly professors and university lecturers from research universities and some principal lecturers from polytechnics.

2. Research and development-oriented academics: mainly lecturers and experts from polytechnics doing R\&D work with companies.

3. Lecturers and other teachers: from research universities and polytechnics, usually not doing research or R\&D work.

4. People in managerial positions: either academic or administrative personnel.

5. Academically-oriented young researchers: usually without doctoral degrees; weak connection to their institutions; all (except one) were from research universities.

6. Personnel in administration or support services without managerial positions.

7. Personnel in administration; participating actively in development work at their institution and networking with colleagues outside their own institution.

8. Research and development-oriented young researchers: from research universities and polytechnics; doing academic research and R\&D work.

The number of clusters was capped at eight because this made it possible to separate Cluster 8 (young R\&D-oriented researchers) from Cluster 2 (R\&D-oriented researchers and teachers). Adding a ninth cluster would have split the first cluster (research-oriented academics) into two clusters, which would have only differed slightly by average age and levels of commitment.

Table 3. here 


\section{Data analysis}

The data that measured attitudes consisted of a series of statements that were assessed by the respondents by choosing one alternative in the Likert scale (ranging from $1=$ totally disagree to $5=$ totally agree). They were also given a sixth option: 'cannot say', and it was possible to proceed with the survey without giving any response to the statement. The statements with high response rates were typically those that expressed general level opinions about quality assurance or the respondent's work environment. Statements that required some specific experience or activity received the lowest response rates.

In some cases when there was a low response rate, the respondents who were critical of quality assurance were willing to give their opinions even if they did not have direct personal experience with the topic. A good example of this is the statement 'The quality assurance system of our university or polytechnic was presented to the audit group truthfully, including its strengths and weaknesses'. In research universities, respondents who were not interviewed during the audit did not usually give their opinion on this but those who were not interviewed and did give an answer were much more critical of it than those who were actually interviewed during the audit.

Some statements revealed more common ways of thinking that reflected the respondents' own experiences. As an example, in research universities, even those whose careers were quite short shared the sentiment behind the statement: 'I feel that various changes and reforms take year by year more time from my real work'.

The actual analysis of the respondents' attitudes consists of three topics selected from the survey: respondents' assessments of the main motivation behind the creation of the quality assurance systems; respondents' general attitudes towards quality assurance; and respondents' commitment and expertise regarding quality work. These topics were chosen because they cover three basic questions related to the reception of the systems. Each topic was analysed with a sum variable consisting of three statements that measure the attitudes toward the same topic from different points of view. The coherence of the sum variables was tested with Cronbach's alpha test. The values of the alpha tests were between 0.736 and 0.760 , which is not high, but still acceptable.

Respondents' assessments of the main motivation behind the creation of the quality assurance systems were measured with a sum variable that consists of the following statements, all of which measure the experience external necessary to build these systems (Cronbach's alpha: 0.760):

- In my opinion, the quality assurance system of our university has been established primarily because ministry of education or similar institution requires it.

- The quality assurance system of our university or polytechnic was built primarily in order to pass the audit.

- In my opinion, the development work of our quality assurance system stopped after the audit.

Only $18 \%$ of the respondents belonging to the cluster 'young researchers' in research universities gave an answer to these questions, which indicates that most of them were cautious about commenting. In general, the last two statements had relatively low response rates from personnel at research universities (58\% and 54\%) and, due to this, they may have suffered from the kind of negative bias that was discussed above. However, in this case there were no essential differences between those who had participated in the development of the quality assurance systems and those who had not.

The respondents from research universities believed that the creation of the quality assurance systems was due to external pressure (Table 4). The polytechnic teaching staff belonging to Clusters 1 and 2 shared similar opinions but the respondents in Clusters 4, 7 and 8 (in other words, people in 
managerial positions, in administrative positions with relatively high levels of networking, and $\mathrm{R} \& \mathrm{D}$-oriented young researchers) did not stress the role of external pressure as much as people in similar clusters from the research universities.

Table 4. here

Differences between clusters were tested with one-way ANOVA and were statistically significant in both types of institutions.

In addition to the external pressure, respondents usually assumed that the systems of quality assurance were created in order to support the work of the universities' management. Respondents in all clusters shared the belief that 'In my opinion, the quality assurance system has been build primarily to support the activities of the management of research university or university of applied sciences'. Similar statements relating to other parts of higher education institutions received lower scores, especially from people in managerial positions at polytechnics. This indicates that the management in the polytechnics tend to see quality assurance as a common interest of all personnel; whereas other personnel consider it as a tool for university management.

The second part of the analysis discusses the general attitudes towards quality assurance. This topic was measured with a sum variable consisting of the following statements (Cronbach's alpha 0.736):

- In my opinion, my university or polytechnic needs a good quality assurance system in order to function properly.

- In my opinion, it is good that we can unify the ways of working in my university or polytechnic with the help of our quality assurance system.

- In my opinion, the quality assurance system supports well my work.

In these statements, the response rates were relatively high, so the risk of bias is quite low. The personnel in research universities were more critical of quality work than their colleagues in the polytechnics (Table 5). Personnel in managerial positions in the polytechnics tended to agree with the statements, whereas the personnel in the same cluster in the research universities were more hesitant, despite this being one of the most positive clusters. Researchers in research universities (Clusters 5 and 8) were the most critical, but many of them refrained from responding.

Table 5. here

Differences between clusters were tested with one-way ANOVA and were statistically significant in both types of institutions.

The third sum variable gives information about the respondents' commitment to, and familiarity with, quality work. It consists of the following variables (Cronbach's alpha 0.756):

- In my opinion, I'm quite familiar with the quality assurance system of my university or polytechnic.

- I participate actively to the maintaining of our quality assurance system by updating its contents or by contributing in some other way to its maintenance.

- I use regularly one or more elements of our quality assurance system, like process handbook, student feedback system or other systems of controlling or feedback.

Because the rate of response to these statements was high, the risk of bias is rather small. This sum reveals the same systematic differences as the sum variable of the general attitude towards quality assurance. All the groups from the polytechnics were more familiar with quality assurance systems than the corresponding groups from the research universities, although in the second cluster, the 
difference is not statistically significant (Table 6). Differences between personnel groups within research universities and polytechnics are greater than they were in the previous topic. At research universities, researchers in Clusters 5 and 8 are the most alienated from the quality assurance process. In general, levels of familiarity with, and commitment to, quality assurance seem to be quite low in research universities. Unlike the previous topics, the majority of the young researchers gave their assessments of the statements pertaining to this sum variable.

Table 6. here

Differences between clusters were tested with one-way ANOVA and were statistically significant in both types of institutions.

People in managerial positions at research universities assessed their expertise and commitment almost as highly as their colleagues at the polytechnics but their attitudes tended to be more critical. For the polytechnics, the clusters relating to administration and support services (Clusters 6 and 7) had different scores rating their commitment to, and familiarity with, quality assurance but they demonstrated almost the same level of acceptance of the quality assurance system. The responses of research-oriented academics (Cluster 1) and teaching-oriented academics (Cluster 3) at research universities reveal the same pattern. This indicates that the relative level of expertise does not explain general attitudes toward quality assurance, see also Cardoso et al. (2012).

In addition to the type of institution and the clusters, gender also has an impact on the reception of quality assurance (Table 7). Women did not emphasise external necessity as a motivation to build quality assurance systems as much as men; and, in general, they had more positive attitudes towards the quality assurance and assessed themselves more familiar and committed to it, see also Cardoso et al. (2012).

Table 7. here

Female respondents in all clusters gave higher scores when asked if quality assurance increased transparency at various levels of university administration. In the polytechnics, women in all clusters gave higher scores than the men when asked how actively they had participated in the building of the quality assurance systems. In the research universities, a similar phenomenon was witnessed in Clusters 1, 2 and 4; that is, in clusters where the respondents had to take some responsibility for the creation of the quality assurance systems.

Respondents in central administration had more positive attitudes toward quality assurance than respondents from other units. There were also statistically significant differences between the responses from members of faculties in research universities and those from fields of study in the polytechnics. At the research universities, these differences may be partly explained by the different proportion of young researchers among the respondents. Consequently, an in-depth analysis of the differences between faculties and fields of study would require more representative data than this study currently possesses.

\section{Conclusion}

The main aim of the study was to analyse the reception of the new quality assurance systems among the personnel in Finnish higher education institutions and to discuss their methodological challenges. The study indicates that cluster analysis makes it possible to classify personnel so that the division includes both types of higher education institutions in Finland. Cluster analysis also provides information on the respondents' individual work contexts. 
With regard to the respondents' actual attitudes, the study shows that there are essential differences between research universities and polytechnics. Although this may partly be explained by the differences in personnel structures and a greater proportion of female respondents (who tended to be more positive towards quality assurance), this does not explain all of the variation, because the differences were even visible when compared cluster-by-cluster or by gender.

In almost all clusters and in all the topics that were measured, the personnel at research universities were more critical of the new modes of quality assurance, see also Cardoso et al. (2012). At research universities, the academically-oriented young researchers were the most critical of quality assurance or they refrained from expressing their opinion. This cluster was practically non-existent in the polytechnics, which further accentuates the difference between the two types of higher education institutions.

The people in managerial positions at the polytechnics were the most committed group among the clusters: whereas at the research universities, the differences between management and other groups (except young researchers) were less. The difference between research universities and polytechnics may partly be explained by the fact that quality work and various audits started to be implemented in polytechnics several years earlier than they were in research universities (Ala-Vähälä \& Saarinen, 2013). The results indicate that the management of the polytechnics rely on the potential advantages that implementing the systems of quality assurance may provide them, whereas people in managerial positions at research universities are (still) adapting to the requirement.

Young researchers at research universities have loose ties with the university organisation, which may explain their unfamiliarity with, and weak commitment to, quality work, and may also explain their critical attitude toward quality assurance and their tendency to refrain from giving an opinion. The position of researchers without doctoral degrees may be different in other countries, where they may not be considered personnel, but doctoral students instead. However, this kind of personnel, working in temporary positions and with an unclear academic status, appears to be growing in number (Hakala, 2009; De Weert, 2001).

The assessments of expertise and commitment to quality assurance revealed slightly different patterns than the assessment of general attitudes. The differences between these clusters were greater and, not surprisingly, the people who participated in university management or were otherwise involved in institutional administration and development also had the most experience in quality work. However, their level of familiarity or expertise may not explain the differences between their attitudes, because even in clusters where respondents had about the same levels of familiarity and expertise, their levels of acceptance were different. Moreover, some clusters had the same levels of acceptance but gave different scores when asked to assess their familiarity with, and expertise in, quality assurance.

The results also indicate that the surveys do not only reveal the respondents' personal experiences with quality assurance but also reflect their shared opinions or shared ways of speaking about quality assurance. In addition, two kinds of biases should be kept in mind in this regard. First, the nature of the question has an impact on a respondent's willingness to give a response: statements that required personal experience elicited lower response rates than general-level statements. Second, people with strong opinions may be more eager to give an answer than those with more moderate attitudes, and this may cause a risk of bias. Therefore, the opinions do not only vary between two alternatives, for or against, but also vary according to a respondent's willingness to take an active stand on the topic or refrain from giving an opinion entirely. This is especially true in the case of young researchers who are 'outsiders' or 'alienated' from the quality assurance process and who may also be alienated from the university institution in general, as the cluster analysis indicated. 


\section{References}

Ala-Vähälä, T. ,2011, Mitä auditointi tekee? Tutkimus korkeakoulujen laadunvarmistusjärjestelmien auditointien vaikutuksista, Korkeakoulujen arviointineuvoston julkaisuja 8:2011.

Ala-Vähälä, T. \& Saarinen, T., 2013, 'Audits of quality assurance systems of higher education institutions in Finland', in Shah, M., \&. Chenicheri, S.N. (Eds.), External Quality Audits: Has it improved quality assurance in universities?, pp. 183-94 (Oxford, Woodhead).

Anderson, G., 2006, 'Assuring quality/resisting quality assurance: academics' responses to 'quality' in some Australian universities', Quality in Higher Education, 12(2), pp. 161-73.

Askling, B., 2001, 'Higher education and academic staff in a period of policy and system change', Higher Education, 41, pp. 157-81.

Brunetto, Y. \& Farr-Wharton, R., 2005, 'Academics' responses to the implementation of a quality agenda', Quality in Higher Education, 11(2), pp. 161 - 180.

Cardoso, S., Rosa, M.J., Santos, C.S., 2012, 'Different academics' characteristics, different perceptions on quality assessment?' Quality Assurance in Education, 21(1), pp. 96-117.

Conference of Ministers responsible for Higher Education "Realising the European Higher Education Area". Communiqué of the Conference of Ministers responsible for Higher Education in Berlin on 19 September 2003. Downloaded from http://www.ehea.info/Uploads/Declarations/Berlin_Communique1.pdf. (accessed 25 August 2008)

De Weert, E., 2001, 'Pressures and prospects facing the academic profession in the Netherlands', Higher Education, 41(1 ISSUE), pp. 77-101.

Eklund, M., 2013, 'External quality assurance in Finnish higher education institutions: two cases the Universities of Tampere and Turku in a new-institutional perspective', University of Helsinki, Faculty of Social Sciences Master's Degree Programme in European Studies Political Science, Administration and Organisations Master's thesis. Available at: http://hdl.handle.net/10138/39875 (accessed 2 April 2015.)

European Association for Quality Assurance in Higher Education (ENQA), 2009, Standards and Guidelines for Quality Assurance in the European Higher Education Area, third edition. (Helsinki, ENQA).

European Ministers of Education. The Bologna Declaration of 1999. Downloaded from http://www.ehea.info/Uploads/Declarations/BOLOGNA_DECLARATION1.pdf. (accessed 2 January 2007)

Haapakorpi, A., 2011, Quality assurance processes in Finnish universities: Direct and indirect outcomes and organisational conditions. Quality in Higher Education, 17(1), pp. 69-81.

Hakala, J., 2009, The future of the academic calling? Junior researchers in the entrepreneurial university. Higher Education, 57, pp. 173-190.

Nyhagen Mathisen, G., Baschung, L., 2013, New organisational structures and the transformation of academic work. Higher Education, 66, pp. 409-423.

Rinne, R., Jauhiainen, A., Simola, H., Lehto, R., Jauhiainen, A., \& Laiho, A., 2012, Valta, uusi yliopistopolitiikka ja yliopistotyö Suomessa. Managerialistinen hallintapolitiikka yliopistolaisten kokemana. Suomen kasvatustieteellinen seura. Kasvatusalan tutkimuksia 58. Jyväskylä 2012.

Rosa, M. J., Cláudia S., Sarrico, C. S., \& Amaral, A., 2012, Academics' perceptions on the purposes of quality assessment. Quality in Higher Education, 18(3), 349-366. 
Talvinen, K., 2012, Enhancing quality: audits in Finnish higher education institutions 2005-2012, Publications of The Finnish Higher Education Evaluation Council. 11:2012. 


\section{Appendix: List of the survey statements assessed by the respondents}

1. In my opinion, my university or polytechnic needs a good quality assurance system in order to function properly.

2. In my opinion, I am quite familiar with the quality assurance system of my university or polytechnic.

3. In my previous jobs, I became familiar with various quality assurance systems (e.g. ISO 9000, TQM, EFQM, CAF).

4. I participate actively in the maintenance of our quality assurance system by updating its contents or by contributing in some other way to its maintenance.

5. In my opinion, the quality assurance system of my university or polytechnic supports my work well.

6. I regularly use one or more elements of our quality assurance system, like the process handbook, student feedback system, and/or other systems of control or feedback.

7. I have contributed actively to the establishment or development of the quality assurance system of my university or polytechnic.

8. In my opinion, the quality assurance system of my university or polytechnic was established primarily to support the activities at the level of units of teaching.

9. In my opinion, the quality assurance system of my university or polytechnic was established primarily to support research or development projects.

10. In my opinion, the quality assurance system of my university or polytechnic was established primarily to support mid-level administration, such as the work done in faculties or institutions.

11. In my opinion, the quality assurance system of my university or polytechnic was established to support the work done in the departments (offices) of student services, financial administration or other similar support, service or administrative units.

12. In my opinion, the quality assurance system of my university or polytechnic was established in order to support the work done by the top management of my university or polytechnic.

13. In my opinion, the quality assurance system of my university was established primarily because the Ministry of Education, or a similar institution, requires it.

14. In my opinion, a quality assurance system increases the transparency of decision making at the level of the units of education.

15. In my opinion, a quality assurance system increases the transparency of decision making at the faculty level, in educational institutions or similar "mid-level" bodies of teaching administration.

16. In my opinion, a quality assurance system increases transparency in the offices of student services, financial administration or other similar support, service or administrative units.

17. In my opinion, a quality assurance system increases the transparency of decision making at the top management level of my university or polytechnic.

18. A quality assurance system makes it easier to search for information about my university or polytechnic. 
19. The data collected by various systems does not give an accurate picture of my work.

20. Over the past few years, it has become easier to address practical matters or my work.

21. A quality assurance system makes it more difficult to address practical matters.

22. In my opinion, it is good that with the help of our quality assurance system we can unify our work methods in my university or polytechnic.

23. Due to the quality assurance system, it is easier to understand administrative processes.

24. In my opinion, due to the quality assurance system it is now easier take care of things in due time.

25. In my opinion, the implementation of the quality assurance system has decreased the level of independence of my own unit.

26. The management of my unit has strongly committed to the use of the quality assurance system.

27. In my opinion, the quality assurance system and my actual way of working are totally disconnected.

28. Audits and external assessments give an accurate picture of the quality of the activities of my university or polytechnic.

29. Audits and external evaluations take too much time in comparison to the benefits that they deliver.

30. If you wish to briefly comment on the quality of work done in your university or polytechnic, you may do so here.

31. In my opinion, my university or polytechnic gave me sufficient information about the audit before it was carried out.

32. I followed the process of the audit with great interest.

33. The audit criteria stated by the Finnish Higher Education Evaluation Committee had a strong impact on the university's or polytechnic's preparation for the audit.

34. Other universities or polytechnics experiences with audits had a strong impact on the on the university's or polytechnic's preparation process for the audit.

35. I was interviewed or participated an interview panel during the audit (yes/no).

36. The quality assurance system of my university or polytechnic was presented to the audit group truthfully, including its strengths and weaknesses.

37. In my opinion, the audit was used as an excuse to implement reforms that would not have succeeded otherwise.

38. During the preparation phase for the audit, many topics that required development were found.

39. The preparation for the audit was a good learning experience.

40. During the preparation process for the audit, my university or polytechnic was discussed in a way that was difficult for me to understand, at least in the beginning. 
41. The quality assurance system of my university or polytechnic was built primarily in order to pass the audit.

42. Without the audit's deadline, the building of a quality assurance system would have proceeded much more slowly.

43. The preparation for the audit happened in a good atmosphere.

44. In my opinion, the development work of our quality assurance system stopped after the audit.

45. In my opinion, a positive audit result increases the credibility of my university or polytechnic on the international stage.

46. A negative audit result deteriorates the reputation of my university or polytechnic.

47. If the audit assessment were not positive, even after the re-audit, it would weaken the position of my university or polytechnic in its negotiations with the Ministry of Education over resources and result targets.

48. If you have other comments about the audits carried out by the Finnish Higher Education Evaluation Council, you can write your comments here.

49. I carry out research full-time or part-time along with other activities.

50. I participate regularly in the research or development work that is undertaken together with private business or public administration.

51. I participate actively in the activities of a scientific society.

52. I participate actively in various working groups, teams, networks or decision forums that have an impact on the activities of my university or polytechnic.

53. I like my current work.

54. In my opinion, the general atmosphere of my work unit is very good.

55. I feel that various changes and reforms progressively take time away from my real work.

56. I meet regularly with people with similar expertise at national or international forums.

57. I keep in contact with decision makers (politicians or public officials) at the local or national level.

58. I keep in regular contact with private companies, public sector units or representatives of business federations. 
Tables:

Table 1. Response rate: research universities

\begin{tabular}{|l|l|l|}
\hline Personnel group & Responses & Response rate \\
\hline Professors & 52 & $15,8 \%$ \\
\hline Associate professors & 18 & $11.8 \%$ \\
\hline Teaching assistants & 14 & $8.9 \%$ \\
\hline University lecturers & 80 & $22.8 \%$ \\
\hline Other university teachers & 34 & $16.3 \%$ \\
\hline $\begin{array}{l}\text { Researchers, including doctoral students having a paid research post in } \\
\text { doctoral schools }\end{array}$ & 132 & $11.6 \%$ \\
\hline Other personnel & 169 & $4.9 \%$ \\
\hline Unknown & 12 & \\
\hline Total & $\mathbf{5 1 1}$ & $\mathbf{8 . 9 \%}$ \\
\hline
\end{tabular}

Table 2. Response rate: polytechnics

\begin{tabular}{|l|l|l|}
\hline Personnel group & Respondents & Response rate \\
\hline Principal lecturers & 35 & $9.0 \%$ \\
\hline Lecturers & 126 & $32.3 \%$ \\
\hline Other teachers & 52 & $13.3 \%$ \\
\hline Other personnel & 165 & $19.5 \%$ \\
\hline Unknown & 12 & \\
\hline Total & $\mathbf{3 9 0}$ & $\mathbf{2 1 . 3 \%}$ \\
\hline
\end{tabular}

Table 3. Information about the clusters

\begin{tabular}{|c|c|c|c|c|c|c|c|c|c|}
\hline & \multicolumn{8}{|c|}{ Cluster } & \multirow[t]{2}{*}{ Total } \\
\hline & $\begin{array}{c}1 . \\
\text { Academics/ } \\
\text { research }\end{array}$ & $\begin{array}{c}2 . \\
\text { Academics/ } \\
\text { R\&D }\end{array}$ & $\begin{array}{c}3 . \\
\text { Academics/ } \\
\text { teaching }\end{array}$ & $\begin{array}{c}4 . \\
\text { Managerial } \\
\text { position }\end{array}$ & $\begin{array}{c}5 . \\
\text { Young } \\
\text { researchers }\end{array}$ & $\begin{array}{c}6 . \\
\text { Adm. \& } \\
\text { support } \\
\text { services }\end{array}$ & $\begin{array}{c}7 . \\
\text { Adm./ } \\
\text { networked }\end{array}$ & $\begin{array}{c}\mathbf{8 .} \\
\text { Young } \\
\text { researchers/ } \\
\text { R\&D }\end{array}$ & \\
\hline Research (1) & $4.36(1.21)$ & $3.61(1.34)$ & 2.39 (1.59) & $2.31(1.59)$ & $4.94(0.37)$ & $\begin{array}{l}1.20 \\
(0.67)\end{array}$ & $1.52(1.11)$ & $4.53(0.77)$ & $\begin{array}{l}3.01 \\
(0.06)\end{array}$ \\
\hline $\begin{array}{l}\text { Research and } \\
\text { development } \\
(2)\end{array}$ & 3.15 (1.49) & $4.16(1.02)$ & $1.73(1.13)$ & $2.80(1.69)$ & $1.43(0.61)$ & $\begin{array}{l}1.35 \\
(0.85)\end{array}$ & $1.58(0.96)$ & $4.44(0.73)$ & $\begin{array}{l}2.48 \\
(1.58)\end{array}$ \\
\hline $\begin{array}{l}\text { Commitment } \\
\text { to institution } \\
\text { (3) }\end{array}$ & $4.05(1.26)$ & $4.08(1.09)$ & $3.03(1.52)$ & $4.51(1.01)$ & $2.04(1.32)$ & $\begin{array}{l}2.48 \\
(1.53)\end{array}$ & $4.31(0.64)$ & $3.53(1.20)$ & $\begin{array}{l}3.51 \\
(1.51)\end{array}$ \\
\hline $\begin{array}{l}\text { Networking } \\
\text { with colleagues } \\
\text { (4) }\end{array}$ & $4.52(0.79)$ & $3.68(1.31)$ & $3.46(1.30)$ & $4.34(0.93)$ & $4.29(1.00)$ & $\begin{array}{l}1.75 \\
(1.06)\end{array}$ & $4.27(0.62)$ & $4.02(1.01)$ & $\begin{array}{l}3.74 \\
(1.37)\end{array}$ \\
\hline $\begin{array}{l}\text { Contacts with } \\
\text { employers (5) }\end{array}$ & $3.02(1.51)$ & $4.28(0.88)$ & $2.77(1.53)$ & $3.37(1.48)$ & $1.36(0.72)$ & $\begin{array}{l}1.97 \\
(1.36)\end{array}$ & $2.67(1.46)$ & $3.81(1.00)$ & $\begin{array}{l}2.88 \\
(1.56)\end{array}$ \\
\hline $\begin{array}{l}\text { Age (average) } \\
\text { in years (6) }\end{array}$ & 49 & 48 & 48 & 51 & 34 & 46 & 42 & 33 & 46 \\
\hline $\begin{array}{l}\text { Doctoral } \\
\text { degree \% (7) }\end{array}$ & $100 \%$ & $3 \%$ & $3 \%$ & $27 \%$ & $36 \%$ & $2 \%$ & - & - & $27 \%$ \\
\hline $\begin{array}{l}\text { Managerial } \\
\text { position \% (8) }\end{array}$ & - & - & - & $100 \%$ & - & - & - & - & $15 \%$ \\
\hline $\begin{array}{l}\text { Participates in } \\
\text { teaching (9) }\end{array}$ & $71 \%$ & $69 \%$ & $100 \%$ & - & - & - & $9 \%$ & - & $42 \%$ \\
\hline $\begin{array}{l}\text { Permanent full- } \\
\text { time job (10) }\end{array}$ & $55 \%$ & $76 \%$ & $77 \%$ & $86 \%$ & $8 \%$ & $65 \%$ & $73 \%$ & - & $62 \%$ \\
\hline $\begin{array}{l}\text { Share of male } \\
\text { respondents }\end{array}$ & $54 \%$ & $43 \%$ & $34 \%$ & $41 \%$ & $49 \%$ & $27 \%$ & $28 \%$ & $47 \%$ & $40 \%$ \\
\hline
\end{tabular}




\begin{tabular}{|l|l|l|l|l|l|l|l|l|l|}
\hline $\mathrm{N}$ & 163 & 102 & 173 & 122 & 80 & 119 & 64 & 43 & 866 \\
\hline
\end{tabular}

Note: The numbers in the first column refer to the cluster criteria presented above. The first six rows show the averages and standard deviations of the Likert scale responses, in which $1=$ totally disagree and 5 = totally agree. Averages below 2 are highlighted in light grey; values above 4 are highlighted in dark grey.

Table 4. Main motivation for creating the quality assurance systems - internal motives or external pressures? ( 1 = strong internal motivation ... 5 = strong external pressure)

\begin{tabular}{|l|l|l|l|l|l|l|l|}
\hline Cluster & \multicolumn{2}{l|}{ Research universities } & \multicolumn{2}{l|}{ Polytechnics } \\
& Average & St deviation & $\mathrm{n}$ & Average & St deviation & $\mathrm{n}$ & significance \\
\hline 1. Academics/research & 3.8 & 0.85 & 86 & 3.7 & 0.77 & 14 & 0.593 \\
\hline 2. Academics/R\&D & 3.6 & 1.01 & 14 & 3.4 & 1.14 & 48 & 0.536 \\
\hline 3. Academics/teaching & 3.9 & 0.98 & 28 & 3.2 & 1.12 & 78 & $0.003 * * *$ \\
\hline 4. Managerial position & 3.5 & 1.03 & 50 & 2.6 & 1.2 & 55 & $0.000 * * *$ \\
\hline 5. Young researchers & 3.8 & 0.63 & 13 & $(2.0)$ & & 1 & \\
\hline 6. Adm. \& support services & 4.0 & 0.99 & 33 & 3.5 & 0.92 & 31 & 0.21 \\
\hline 7. Adm./networked & 3.7 & 0.79 & 13 & 2.9 & 1.20 & 23 & 0.14 \\
\hline 8. Young researchers/R\&D & 4.4 & 0.60 & 7 & 2.8 & 0.73 & 9 & $0.000 * * *$ \\
\hline Total & $\mathbf{3 . 8}$ & $\mathbf{0 . 9}$ & $\mathbf{2 4 4}$ & $\mathbf{3 . 1}$ & $\mathbf{1 . 1}$ & $\mathbf{2 5 9}$ & $\mathbf{0 . 0 0 0} * * *$ \\
\hline
\end{tabular}

Table 5. General attitude towards quality assurance: research universities and universities of applied sciences ( $1=$ critical attitude $\ldots 5=$ positive attitude.)

\begin{tabular}{|l|l|l|l|l|l|l|l|}
\hline Cluster & \multicolumn{2}{l|}{ Research universities } & \multicolumn{2}{l|}{ Polytechnics } \\
\hline & Average & St deviation & $\mathrm{n}$ & Average & St deviation & $\mathrm{n}$ & significance \\
\hline 1. Academics/research & 2.9 & 0.80 & 122 & 3.4 & 0.76 & 20 & $0.011^{*}$ \\
\hline 2. Academics/R\&D & 3.3 & 0.79 & 23 & 3.4 & 0.89 & 71 & 0.389 \\
\hline 3. Academics/teaching & 2.9 & 0.90 & 50 & 3.4 & 0.92 & 106 & $0.007^{* *}$ \\
\hline 4. Managerial position & 3.3 & 0.99 & 61 & 4.1 & 0.70 & 57 & $0.000^{* * *}$ \\
\hline 5. Young researchers & 2.6 & 0.75 & 45 & $(3.5)$ & & $(1)$ & \\
\hline 6. Adm. \& support services & 3.1 & 0.91 & 44 & 3.5 & 0.61 & 44 & $0.013^{*}$ \\
\hline 7. Adm./networked & 3.3 & 0.83 & 18 & 3.8 & 0.81 & 34 & $0.038^{*}$ \\
\hline 8. Young researchers/R\&D & 2.7 & 0.84 & 15 & 3.5 & 0.60 & 17 & $0.004^{* *}$ \\
\hline Total & $\mathbf{2 . 9}$ & $\mathbf{0 . 8 8}$ & $\mathbf{3 8 9}$ & $\mathbf{3 . 5}$ & $\mathbf{0 . 8 4}$ & $\mathbf{3 5 0}$ & $\mathbf{0 . 0 0 0 * * *}$ \\
\hline
\end{tabular}

Table 6. Expertise and commitment to quality assurance: research universities and universities of applied sciences ( $1=$ poor expertise and commitment ... $5=$ excellent expertise and commitment)

\begin{tabular}{|c|c|c|c|c|c|c|c|}
\hline \multirow[t]{2}{*}{ Cluster } & \multicolumn{3}{|c|}{ Research universities } & \multicolumn{3}{|c|}{ Polytechnics } & \multirow{2}{*}{$\begin{array}{l}\text { Statistical } \\
\text { significance }\end{array}$} \\
\hline & Average & St deviation & $\mathrm{n}$ & Average & St deviation & $\mathrm{n}$ & \\
\hline 1. Academics/research & 2.9 & 1.08 & 139 & 3.4 & 0.86 & 21 & $0.012 *$ \\
\hline 2. Academics/R\&D & 3.0 & 1.03 & 27 & 3.3 & 1.06 & 72 & 0.213 \\
\hline 3. Academics/teaching & 2.5 & 0.97 & 59 & 3.3 & 1.00 & 110 & $0.000 * * *$ \\
\hline 4. Managerial position & 3.7 & 1.01 & 62 & 4.4 & 0.67 & 58 & $0.000 * * *$ \\
\hline 5. Young researchers & 1.7 & 0.83 & 73 & $(3.7)$ & & $(1)$ & \\
\hline 6. Adm. \& support services & 2.5 & 1.15 & 63 & 2.9 & 1.13 & 50 & $0.048 *$ \\
\hline
\end{tabular}




\begin{tabular}{|l|l|l|l|l|l|l|l|}
\hline 7. Adm./networked & 2.9 & 1.04 & 25 & 3.5 & 1.17 & 38 & 0.054 \\
\hline 8. Young researchers/R\&D & 2.0 & 1.06 & 22 & 2.7 & 1.01 & 19 & $0.040^{*}$ \\
\hline Total & $\mathbf{2 . 7}$ & $\mathbf{1 . 1 7}$ & $\mathbf{4 7 0}$ & $\mathbf{3 . 4}$ & $\mathbf{1 . 0 9}$ & $\mathbf{3 6 9}$ & $\mathbf{0 . 0 0 0 ^ { * * * }}$ \\
\hline
\end{tabular}

Table 7. The impact of gender on attitudes and commitment to quality assurance

\begin{tabular}{|c|c|c|c|c|c|c|c|c|c|}
\hline & & \multicolumn{4}{|c|}{ Research universities } & \multicolumn{4}{|c|}{ Polytechnics } \\
\hline & & Average & St dev. & $\mathrm{n}$ & Sig. ${ }^{*}$ & Average & St deviation & $\mathrm{n}$ & Sig. \\
\hline \multirow{2}{*}{$\begin{array}{l}\text { Internal vs. } \\
\text { external } \\
\text { motivation }\end{array}$} & Women & 3.7 & 0.92 & 143 & \multirow{2}{*}{0.008} & 3.0 & 1.1 & 172 & \multirow{2}{*}{$\begin{array}{l}0.00 \\
* * *\end{array}$} \\
\hline & Men & 4.0 & 0.86 & 107 & & 3.5 & 1.1 & 97 & \\
\hline \multirow[t]{2}{*}{ General attitude } & Women & 3.1 & 0.80 & 225 & \multirow[t]{2}{*}{0.000} & 3.7 & 0.76 & 230 & \multirow{2}{*}{$\begin{array}{l}0.000 \\
* * *\end{array}$} \\
\hline & Men & 2.8 & 0.95 & 178 & & 3.3 & 0.91 & 133 & \\
\hline \multirow{2}{*}{$\begin{array}{l}\text { Familiarity and } \\
\text { commitment }\end{array}$} & Women & 2.8 & 1.2 & 271 & \multirow[t]{2}{*}{0.023} & 3.6 & 1.08 & 247 & \multirow{2}{*}{$\begin{array}{l}0.000 \\
* * *\end{array}$} \\
\hline & Men & 2.5 & 1.1 & 217 & & 3.1 & 1.05 & 136 & \\
\hline
\end{tabular}

*Pairwise t-test between men and women.

${ }^{\text {i }}$ Column "statistical significance" indicates the statistical significance between research universities and universities in each cluster unless otherwise stated. 